\title{
Role of Small and Medium Business in Stimulation of Export in Republic of Armenia
}

\author{
Koryun Atoyan
}

\begin{abstract}
In July 2011, the European Commission said it would open a consultation on the definition of SMEs in 2012. In Europe, there are three broad parameters which define SMEs:

- micro-entities are companies with up to 10 employees

- Small companies employ up to 50 workers

- Medium-sized enterprises have up to 250 employees [1].

The European definition of SME follows: "The category of micro, small and medium-sized enterprises (SMEs) is made up of enterprises which employ fewer than 250 persons and which have an annual turnover not exceeding 50 million euro, and/or an annual balance sheet total not exceeding 43 million Euro.

EU member states have had individual definitions of what constitutes an SME. For example, the definition in Germany had a limit of 255 employees, while in Belgium it could have been 100 . The result is that while a Belgian business of 249 employees would be taxed at full rate in Belgium, it would nevertheless be eligible for SME subsidy under a European-labelled programme.
\end{abstract}

Keywords - small and medium business, external trade, economic policy, World Trade organization.

\section{INTRODUCTION}

$\mathrm{I}_{\mathrm{p}}^{\mathrm{N}}$ order to understand the role of small and medium practices (SMPs) in providing business support to small and medium-sized enterprises it is important to set out the general context within which this key role operates. SMEs are now crucial to most developed and developing countries. For example, in the European Union, SMEs contribute to over $99 \%$ of all enterprises and 100 million jobs, representing $67.1 \%$ of private sector employment. Extant theory and evidence demonstrates that owners and managers of SMEs utilize external sources of advice and support services primarily because of a gap in their internal resource base. SMEs need to have competencies in order to survive in a changing environment and buying-in resources, in terms of advice and support, is a dominant approach for their survival and development. It is this resource gap and changing environment faced by SMEs that creates a role for SMPs as key business advisers [2].

The external trade and economic policy of Republic Armenia was generated and carried out on liberal bases. Armenia was included in the list of the countries showing a

Koryun Atoyan is with the Armenian State University of Economics, Yerevan, 0025. Armenia (phone: +37491-211917, fax: +37410-593422. Email: Prof_Mkhitaryan@yahoo.com). high level of economic freedom and in 2011 having bypassed France, has taken 36-th place, according to results of the annual researches which have been carried out by fund Wall Street Journal and Heritage.

The main and preferential directions of external trade and economic policy are integration of Republic of Armenia into economic, stimulation of export, involving of investments, creation of the favorable environment for development of external economic activities, reduction of negative balance of trading balance, development of interstate economic cooperation with other countries, development of the corresponding infrastructures raising productivity of external trade and economic activity, etc.

From the point of view of acceleration of integration process for Republic of Armenia very important to develop the multilateral economic cooperation and qualitatively new bases, as within the limits of the CIS /Commonwealth of Independent States/ without an output of a zone of free trade and in business of formation of the general market, and behind its frameworks. Foreign trade in Armenia adjusted by a mode, established legislative and statutory acts, and also bilateral both multilateral international and intergovernmental agreements of RA.

The World Trading Organization is the unique international organization which is engaged in an establishment of rules of trade between people which purpose is the help to manufacturers of the goods and services, to exporters and importers in realization of the business [3].

\section{PARTNERSHIP AND COOPERATION WITH DIFFERENT COUNTRIES}

On November 22, 2002 the Working party has approved the report on membership of Armenia and has transferred the application of Armenia in General advice of WTO. On December 10, 2002 General Board has approved the application for membership of Armenia in WTO. Since February, 5th, 2003 Armenia became official 145-th member of WTO.

Mutual relations between Armenia and the European Union, including trade and economic cooperation are settled by the agreement on Partnership and Cooperation.

The European Union and Armenia have signed the agreement on partnership and cooperation which has come into force with July 1, 1999. Signing of the following agreement has opened new page for cooperation of EU- 
Armenia. The agreement was desire of two parties in an establishment of close cooperation and creation of a legal basis for multilateral political and economic cooperation.

The basic purposes of the agreement on partnership and cooperation are:

- Maintenance of cooperation of EU-Armenia, developing political mutual relations,

- Maintenance of respect the principles of democracy, leadership of the law over human rights and transition to market economy,

- Stimulation of trading communications between the parties, and also legal, social, financial, scientific, civil cooperation.

Within the limits of policy of the European neighborhood Armenia has the program of actions which is called to support trade of EU and integration of economy. Realization of the program of actions will enable the state gradually to be ready to cooperation, to carry out from EU and to keep universality of a free trading zone. The conclusion of the agreement of universal free trade will promote occurrence of Armenia on the European market and to stimulate the further European investments in Armenia.

Armenia has signed agreements on free trade with the countries of the Commonwealth of Independent States, except for Azerbaijan and Uzbekistan. Armenia operates in a mode of free trade with Belarus, Georgia, Moldova, Kazakhstan, Russian Federation, Ukraine, Tajikistan and Republic of Kirghizia. According to agreements mutual non-use of taxes and duties were provided.

Armenia together with Albania, Bulgaria, Georgia, Greece, Moldova, Romania, the Russian Federation, Serbia, Turkey and Ukraine is a member of the organization of the Black Sea Economic Cooperation (BSEC). The purpose of multilateral economic initiative BSEC is encouragement of cooperation in Black Sea region. All three South Caucasian countries used the generalized system of privileges of EU. According to position about the generalized system of privileges which operates from June, 1st, till December, 1st, 2011, all have entered into the list developed and well operated, that suggests to enter on the market of EU on favorable conditions. The system of the generalized privileges of EU is the trading arrangement on which 176 countries and to regions of EU the preferential input in the market of the European Union is given, lowering cost of the goods, at an input on the market of EU.

The especial purpose of the agreement on steady development and the management, offering reduction of additional tariffs, assistance to developing states in the given spheres is in processes of ratification and application of the international conventions.

Armenia since January, first up to the end of 2011 is beneficiary of systems total privileges. Beneficiaries of systems total privileges should ratify also and productively apply 27 international conventions, characteristic to spheres of human rights, the cores criteria of work, steady development and management.
The trading mode with some countries is defined by bilateral interstate agreements, proceeding from principles of trade and economic cooperation.

Thus, on May, 27th, 1992 between the governments of Republic Armenia and the Arabian Republic of Egypt in Cairo the agreement „About the economic, scientific and technical agreement" has been signed. According to positions of the given convention between Armenia and Egypt with the purpose of development of economic, scientific and technical cooperation, according to decision N 222 from May, 24th 1993, the Armenian-Egyptian intergovernmental commission which purpose is development of projects of programs of cooperation in spheres of the industry, agriculture, power, transportation, education, sports and other spheres, and also granting of the information and consultations, control of execution of positions of the agreement has been created.

The Belarus intergovernmental commission concerning economic cooperation has been based according to the agreement " Between governments of Armenia and Belarus about free trade ".

The Ukrainian intergovernmental commission concerning economic cooperation has been based according to the agreement, Between the governments of Armenia and Ukraine about free trade". On February, 25th, 2002 the new structure of the Armenian part of the intergovernmental commission has been approved. After that it has been reached a number of arrangements concerning directions of cooperation. In particular, opportunities of cooperation in spheres of the industry, transport, tourism, taxes and the customs duties, public health services, a science and information, culture are discussed the present condition of trade and economic relations.

The Austrian intergovernmental commission has been created between governments RA and Austria on the basis of a bilateral agreement about external economic relations on April, 26th, 1994. The commission has presented discussion such questions representing bilateral interest, as a condition and prospects of economic cooperation, prospect of investment cooperation, the further development of bilateral standard-legal base, etc.

Works in a direction of development of cooperation with direct neighbors of Armenia - Islamic Republic of Iran, both bilateral cooperation, and creation of the favorable environment for the organization of trade between the parties are conducted.

Above specified countries are the basic trading partners of Armenia. Last years on a level of volumes of trade to them have come nearer some more.

The leading partner of Armenia is Russia, however in difference from the beginning of 90-s' continues to remain, commodity circulation Armenia-Russia has fallen a low level. Except Turkmenistan, with other states trading balance RA was and remains negative.

Despite of influence of World financial crisis in 2009, export to Armenia tends to growth. 
TABLE I

THE COUNTRIES EXPORTERS, 2010-2013 (\%)

\begin{tabular}{|l|l|l|l|l|}
\hline The country & 2010 & 2011 & 2012 & 2013 \\
\hline Russia & 19.7 & 14.3 & 15.4 & 16.8 \\
\hline Germany & 17.4 & 16.2 & 12.7 & 11.9 \\
\hline Bulgaria & 5.6 & 9.6 & 15.0 & 11.5 \\
\hline THE USA & 5.0 & 10.1 & 7.9 & 7.6 \\
\hline $\begin{array}{l}\text { The } \\
\text { Netherlands }\end{array}$ & 12.4 & 7.8 & 9.5 & 8.8 \\
\hline Belgium & 8.5 & 5.9 & 7.0 & 5.3 \\
\hline
\end{tabular}

\begin{tabular}{|c|c|c|c|c|}
\hline The country & 2010 & 2011 & 2012 & 2013 \\
\hline $\mathbf{E U}$ & 54.2 & 44.8 & 48.1 & 45.7 \\
\hline THE CIS & 23.6 & 18.9 & 19.1 & 19.8 \\
\hline THE USA & 5.0 & 10.1 & 7.9 & 7.6 \\
\hline Other countries & 17.2 & 26.2 & 24.9 & 26.9 \\
\hline
\end{tabular}

TABLE II

THE BASIC EXPORTED GOODS, 2010-2013./THOUSAND US \$/

\begin{tabular}{|l|l|l|l|l|}
\hline The goods & 2010 & 2011 & 2012 & 2013 \\
\hline $\begin{array}{l}\text { Jewels, } \\
\text { metal }\end{array}$ & 174662.1 & 105075.1 & 134049.4 & 196441.4 \\
\hline $\begin{array}{l}\text { Not } \\
\text { precious } \\
\text { metal }\end{array}$ & 346792.7 & 231152.0 & 332428.9 & 364728.5 \\
\hline Minerals & 174175.6 & 145624.8 & $\mathbf{3 0 6 7 5 2}$ & $\mathbf{3 9 8 7 8 3 . 6}$ \\
\hline Meal & 176228.1 & 99570.2 & 131065.6 & 183915.7 \\
\hline Clothes & 40202.4 & 14825.7 & 6751.2 & $\mathbf{8 3 8 2 . 3}$ \\
\hline
\end{tabular}

In 2013 export has grown on $28 \%$ in comparison with the last year. As to 2013, the basic countries of export are EU $(45.7 \%)$, the CIS (19.8\%), the Russian Federation (16.8\%), Bulgaria (11.5\%), Iran (8\%), the USA (7.6\%). In 2013 the investment have grown on $10.7 \%$ in comparison with the last year. As to 2013, the countries importers are the CIS (29.1\%), EU (28.2 \%), the Russian Federation (21.5\%), China (9.8\%), Germany (5.9\%) and Turkey (5.8\%).

Our study revealed that $47.6 \%$ of SMEs are engaged in trade, $34.4 \%$ of SMEs provide services $15.5 \%$ are in manufacturing and $2.2 \%$ are in construction industries. For the purposes of this research, SMEs have been defined pursuant to the Republic of Armenia Law on "State Support of Small and Medium Entrepreneurship." It is worth noting that Armenia's micro businesses are more involved in trade $(55.2 \%)$ than small and medium enterprises [4].

Small and Medium Enterprises in Armenia deal with banks mostly for their transfer and loan needs. According to research, timely and quick service by a bank is of utmost importance for SMEs. The decisive factor here is how fast they can get a loan or the transfer needed.

"Small and Medium Entrepreneurship Development National Centre" Fund (SME Development National Centre of Armenia) was established by Government of Armenia in 2002.
SME Development National Centre is authorized to provide state support to small and medium entrepreneurship (SME) in the country. The support is provided through implementation of annual SME State Support Programs with resources allocated from State budget.

SME Development National Centre of Armenia is governed by Board of Trustees headed by the Minister of Economy.

SME Development National Centre of Armenia carries out its activities through the well developed network of regional branches and representative offices covering all regions of Armenia coordinated by the central office in Yerevan.

Since 2002 thousands of SMEs benefited from various support programs designed for start-up and operating companies.

SME Development National Center of Armenia's activities are targeted at:

- Ensuring a dialogue between SMEs and state

- Increasing efficiency and competitiveness of SMEs

- Ensuring availability of business development services for SMEs

- Expanding the financial opportunities for SMEs

- Promoting innovations and R\&D activities of SMEs

- Assistance for establishment of new SMEs

- Supporting internationalization of SMEs' activities [5].

As of July 1, 2013 in the frameworks of SME State Support Program 2013, 9409 start-up and operating SMEs have received support from SME Development National Centre of Armenia in the directions of loan guarantees provision, startup businesses support, sales and export promotion, training, information and consulting programs.

TABLE III

SUPPORT DIRECTIONS AND NUMBER OF SUPPORT APPLICATIONS IN ARMENIA

\begin{tabular}{|c|c|}
\hline Support direction & $\begin{array}{c}\text { Number of support } \\
\text { applications satisfied as } \\
\text { of } 01.07 .2013\end{array}$ \\
\hline Business information and consulting & 8589 \\
\hline Training & 274 \\
\hline Start-up businesses & 233 \\
\hline Financial support & 102 \\
\hline Loan guarantees & 18 \\
\hline $\begin{array}{c}\text { Support provided in the framework of } \\
\text { Enterprise Europe Network Correspondence } \\
\text { Center activities }\end{array}$ & 141 \\
\hline Local Economic Development Programmes & 10 communities \\
\hline Sectoral support programmes & 52 \\
\hline Total & 9409 \\
\hline
\end{tabular}

$6.2 \%$ of SMEs operate in Yerevan, and $93.8 \%$ in the marzes of Armenia, mostly in remote an bordering regions.

In order to expand the scope of activities stipulated by implementing program directions, as well as to elaborate SME 
support new tools and programs, the SME Development National Center of Armenia cooperates with Numerous international organizations and agencies.

\section{2 "Local/Regional Economic 11HS It Development Network as decisive CROSSBORDER leverage point for enhanced cooperation competitiveness in the Black Sea 4. Basin regions (Black Sea LRED- Net)"}

Within the framework of the Black Sea Basin Joint Operational Programme 2007-2013, SMEDNC of Armenia constitutes the "Local/Regional Economic Development Network as decisive leverage point for enhanced competitiveness in the Black Sea Basin regions (Black Sea LRED-Net)" program coordinator. The partners of the program are organizations providing business services of Greece, Bulgaria, Moldova and Georgia, as well as the Gegharqunik Chamber of Commerce. The program started in July 2013, the duration of the program is 24 months.

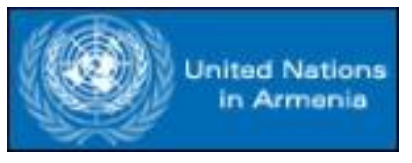

\section{"Support to SME Development in Armenia” SME Development National Center of Armenia/UNDP joint project}

"Support to SME Development in Armenia" SME Development National Center / UNDP joint project has started its activities in September 2004.

Main objective of the Project is provision of support to small and medium enterprises at central and regional levels directly and through strengthening the capacities of SME Development National Center of Armenia. The support is provided through implementation of Project Annual Work plans developed in line with SME Annual State Support programs with resources allocated from SME Development National Center and UNDP funds.

\section{CONCLUSION}

Development and functioning of the program of expansion and assistance to volumes of export of small and medium business demands the decision of three general questions:

1. Absence of potential of export of small and average business in Armenia. The Export potential should contain that list of the goods and services which will be based on priorities of absolute and relative advantage of RA, opportunities and ways of their realization with the instruction (according to a kind, time scales, an estimation of the markets of realization, etc.). We shall note also, that in Republic the certain works in this direction are spent. In particular, the Armenian agency of Development carries out the program "Export and development ".

2. Assistance to promotion of an export potential of small and average business PA.

Assistance of Government RA to process экпорта should contain институциональное reforming of potential and the control over resources (with the instruction of all possible mechanisms and tools of influence - credit, tax, bank, visa, etc.). After development of the program it is necessary to provide preconditions for realization of the program in the form of problems and actions presented below:

* Elimination of the administrative and technical barriers (interdictions) interfering export, simplification of customs procedures and improvement of system of standardization.

* Formation of infrastructures of development and expansion of export, ordering of activity, creation of agency of assistance to export, to which functions should be studying of foreign markets, development of projects of trading contracts, granting of information and advertising services, electronic trade, the organization of the international exhibitions and fairs.

* Formation of system of financing of foreign trade and insurance.

* Creation of insurance bank of export-import in RA.

* Formation of works of an industrial infrastructure, including system of leasing activity, in particular creation, perfection and ordering of services transport, communications, packing's, storages, quality checks.

* Formation of information systems, and also improvement of system of granting of technical and consultative services, introduction the Internet and other information systems, assistance to the consultative companies.

* Development of human resources, preparation and improvement of professional skill of managers, designers, designers, experts of maintenance of quality of marketing and other experts.

* Creation of institute of sales representatives of Armenia in abroad.

3. The Organization of works on assistance and expansion of export of small and average business. For the decision of main problems it is necessary to create corresponding working group for scientifically-practical maintenance of the program.

Ultimate goal of realization of the program is creation of favorable conditions for all subjects of enterprise activity, the only stipulation for which is presence of an export direction of the goods and services.

\section{REFERENCES}

[1] Michael Jonker. Survival Kit for Small and Medium Businesses - Profit from Your Business Risks. /January 2, 2006/

[2] Brunnermeier, M. K. and L. H. Pedersen. 2009. "Market Liquidity and Funding Liquidity.” Review of Financial Studies 22 (6): 2201-38. http://dx.doi.org/10.1093/rfs/hhn098

[3] http://www.wto.org/

[4] National Statistic Service Republic of Armenia: Main Statistical Data. Yerevan, Armenia 2013. www.armstat.am

[5] Small and Medium Entrepreneurship Development National Centre of Armenia. http://www.smednc.am/\#sthash.T36LTTWe.dpuf. 